\title{
PENGEMBANGAN MEDIA PEMBELAJARAN INTERAKTIF MATERI PEMBELAJARAN KOMPUTER TERAPAN JARINGAN KELAS X TKJ
}

\author{
Noor Wahid Septiawan', Afis Pratama ${ }^{2}$ \\ SMK Al Furqon ${ }^{1}$, Universitas IVET ${ }^{2}$ \\ Email: wahid.septiawan@gmail.com
}

Diterima: April 2019. Disetujui: Mei 2019. Dipublikasikan: Juni 2019

\begin{abstract}
ABSTRAK
Kurangnya media pembelajaran dalam proses pembelajaran di SMK Al Furqon Demak yang selama ini bersumber dari buku dan ceramah. Tujuan penelitian ini untuk menghasilkan media pembelajaran jaringan komputer dengan adobe flash cs6 materi pembelajaran komputer terapan jaringan kelas sepuluh, mengetahui desain, realisasi, unjuk kejadian tingkat kelayakan media pembelajaran komputer terapan jaringan.

Penelitian ini menggunakan menggunakan jenis penelitian pengembangan (Research and development). Proses penelitian yang dilakukan adalah: (1) potensi masalah, (2) analisis kebutuhan, (3)pembuatan software, (4) uji validasi oleh ahli, (5) revisi produk, (6) layak. Media pembelajaran diuji oleh ahli media dan ahli materi. Pengguna dalam uji coba siswa kelas sepuluh SMK Al Furqon Demak berjumlah 26 siswa. Metode pengumpulan data menggunakan angket. Teknik yang digunakan menggunakan analisis deskriptif yang diungkapkan dalam distributif skor dan persentase terhadap katagori skala penilaian 1, 2, 3, dan 4 yang telah ditentukan.

Hasil analisis menunjukkan kualitas media yang dihasilkan sebagai berikut: kelayakan media pembelajaran menurut ahli media memperoleh persentase total sebesar 100\%, sedangkan menurut ahli materi memperoleh persentase sebesar $93 \%$, dan hasil uji coba pengguna di lapangan memperoleh persentase sebesar $86 \%$. Dengan demikian dapat disimpulkan bahwa media pembelajaran memiliki kualitas yang baik dan dapat digunakan sebagai alat bantu pembelajaran.

Kata kunci: media pembelajaran, interaktif, kelayakan
\end{abstract}

\begin{abstract}
Lack of learning media in the learning process in SMK Al Furqon Demak wich has been sourced from books and lecture. The purpose of this study is to produce Jaringan Komputer learning media with adobe flash sc6 komputer terapan jaringan learning material for class 10, Know the desigen, realization, feasibility performance komputer terapan jaringan learning media.

This study uses the type Reseach and Development. The research process carried out is: (1) potentional problem, (2) needs analysis, (3) making software, (4) test validation by experts, (5) media revision, (6) worthy. Medi learning is tested by media experts and metter experrts. The user in the trial uses the tenth grade of SMK Al Furqon Demak totaling 26 students. Metide of data collection using questionneire. The techniq uses descriptive annalysisi expressed in distributive scores and percentages of scoring categories $1,2,3$, and 4 wich has been specified.

The results of the analysis show the quality of the media produced as follows: the feasibility of learning media according to media experts gets a total percentage of $100 \%$, while according to material experts get a percentage of $93 \%$, and the results of trial users on the field get a percentage of $86 \%$. Thus it can be concluded that learning media has good quality and can be used as a learning aid.
\end{abstract}

Keywords: learning media, interactive, feasibility 


\section{LATAR BELAKANG MASALAH}

Kemajuan Ilmu Pengetahuan dan Teknologi menuntut berkembangnya ilmu pada bidang pendidikan. Berbagai metode diterapkan guna meningkatkan kualitas peserta didik di dalam Pendidikan. (Azhar Arsyat 2010).

Salah satu materi yang dipelajari pada Sekolah Menengah Kejuruan (SMK) adalah Komputer Terapan Jaringan. Sesuai pengalam selama praktik pengalaman lapangan yang berlangsung selama 45 hari dan hasil wawancara kepada guru dan siswa yang dilaksanakan di SMK Al Furqon masih banyak siswa yang belum memahami dasar-dasar dalam jaringan komputer dan penerapannya dalam jaringan komputer dan selama ini mereka hanya mencari informasi dari internet. Berdasarkan permasalahan di atas, dibutuhkan suatu media yang mampu memberikan pemahaman lebih dalam dan menyenangkan mengenai Komputer Terapan Jaringan serta dapat meningkatkan ketertarikan siswa untuk belajar.

Oleh karena itu media yang dibuat belum diketahui kelayakannya, sehingga peneliti bermaksud melakukan penelitian dengan judul "Pengembangan Media Pembelajaran Interaktif Mata Pelajaran Komputer Terapan Jaringan Siswa Kelas X TKJ" yang salah satu tujuannya adalah untuk mengetahui tingkat kelayakan media pembelajaran, hal ini sesuai dengan penelitian eksperimen dengan menguji tingkat kelayakan media pembelajaran. (Association of Education and Communication Technology/AECT) di Amerika, menyatakan bahwa media sebagai segala bentuk dan saluran yang digunakan orang untuk menyalurkan pesan/informasi. Penelitian ini akan dilaksanakan di SMK Al Furqon dan subjek penelitiannya adalah siswa kelas TKJ. Peneliti menerapkan model penelitian pengembangan $\mathrm{R} \& \mathrm{D}$ (Research and Development).

Berdasarkan uraian di atas peneliti bermaksud untuk membuat suatu media pembelajaran materi pelajaran komputer terapan jaringan, perbedaan dari media ini dengan media yang lainya adalah dapat digunakan di sistem operasi android maupun di sistem operasi Windows dan terdapat latihan soal yang bisa digunakan untuk menguji kemampuan siswa yang diharapkan bisa menambah minat belajar siswa supaya peserta didik lebih memahami mengenai jaringan komputer serta peralatan-peralatan pendukungnya yang selama ini hanya penyampaian secara ceramah dan mencari sumber materi secara mandiri seperti mencari materi di internet.

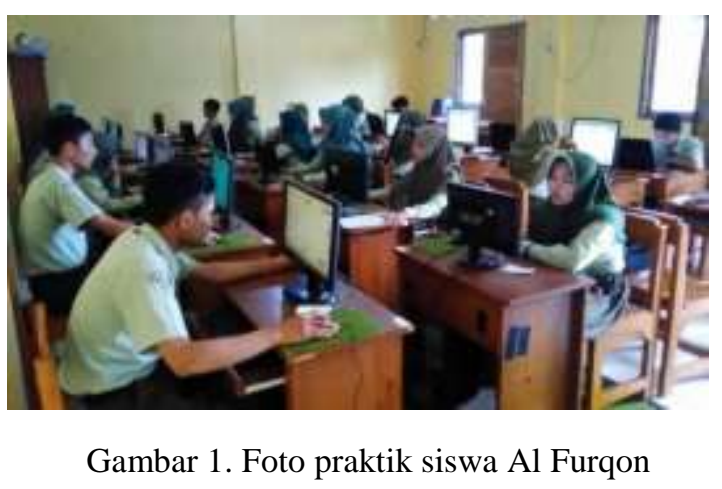

\section{METODE PENELITIAN}

Metode yang digunakan dalam penelitian ini menggunakan penelitian pengembangan (Research and Development). Metode penelitian pengembangan adalah metode yang digunakan untuk menghasilkan produk tertentu, dan menguji keefektifan produk tersebut. Sugiyono(2009). Berikut langkahlangah dalam penelitian pengembangan :

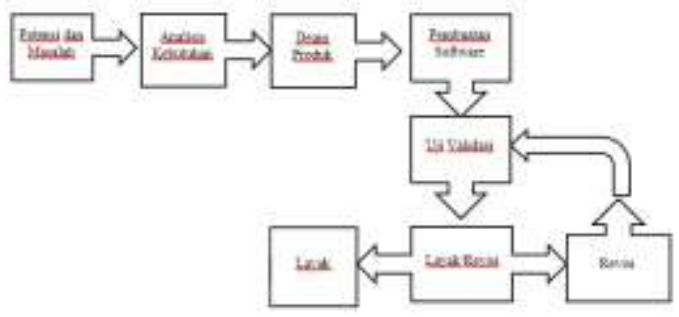

Gambar 2, Langkah-langkah menggunakan metode R\&D Sugiyono( 2009)

\section{Potensi Masalah}

Potensi merupakan segala sesuatu yang bila didayagunakan akan memiliki nilai tambah. Di mana masalah merupakan 
penyimpanan antara yang diharapkan dengan apa yang terjadi (Laily, 2011). Pada tahap ini akan dicari masalah yang di hadapi oleh siswa dan guru dalam kegiatan belajar mengajar serta potensi apa yang dapat dikembangkan untuk dikembangkan untuk mengatasi masalah yang ada.

\section{Analisis Kebutuhan}

Tahap analisis kebutuhan digunakan untuk menentukan apa saja yang dibutuhkan untuk membuat suatu media pembelajaran, baik kebutuhan hardware maupun software, dan mencari materi yang sesuai dengan silabus, serta menganalisis media seperti apa yang dibutuhkan oleh guru dan siswa untuk membantu proses pembelajaran.

\section{Desain Produk}

Desain produk di sini berupa pembuatan rancangan media yang meliputi:

\section{a. Desain materi}

Desain materi ini ditentukan materi yang akan disajikan dalam media pembelajaran yang berupa gambar dan tex dan juga terdapat latihan soal yang bisa di gunakan.

\section{b. Desain navigasi}

Pada tahap ini di rancang struktur navigasi dari media pembelajaran yang akan di buat. Melalui struktur tersebut akan terlihat aliran dari program media pembelajaran yang di buat.

\section{c. Desain tampilan layer}

Pada tahap ini di rancang bagaimana tampilan pada setiap frame maupun layer media pembelajaran agar pembuatan program terstruktur. Desain tampilan layar disajikan dalam bentuk Story board. Dan Story board ini digunakan dalam pembuatan media pembelajaran

\section{Pembuatan Media}

Pembuatan media perangkat lunak dilakukan sesuai desain produk yang di buat. Pada tahap ini, pembuat mengimplementasikan desain ke dalam bentuk aplikasi dengan menggunakan software tertentu dan menyatukannya menjadi satu kesatuan yang utuh.

\section{Uji Validasi}

Tahap ini merupakan tahap pengujian yang dilakukan oleh ahli materi yakni guru yang menampu materi pelajarn komputer terapan jaringan dan ahli media untuk mengetahui kesalahan dan kelemahan dari produk yang dibuat untuk diperbaiki.

\section{Revisi produk}

Pengujian pada tahap ini melibatkan pengguna sebagai calon pemakai produk. Hasil uji coba yang diperoleh merupakan contoh yang siap diterapkan pada lingkungan yang lebih luas.

\section{Uji Produk}

Pengujian pada tahap ini melibatkan pengguna sebagai calon pemakai produk. Hasil uji coba yang diperoleh merupakan contoh yang siap diterapkan pada lingkungan yang lebih luas.

\section{Layak}

ini adalah tahap penyempurnaan program sesuai masukan yang diberikan oleh pengguna.

\section{Teknik analisis data}

Teknik analisis data yang dilakukan pada tahap pertama adalah menggunakan deskriptif kualitatif yaitu memaparkan produk media hasil rekayasa setelah diimplementasikan dalam bentuk produk jadi, dan menguji tingkat validasi dan keandalan produk. Pada tahap kedua menggunakan deskriptif kuantitatif untuk memaparkan mengenai kelayakan produk untuk diimplementasikan ke dalam materi merakit komputer terapan jaringan. Skala dalam pengukuran kelayakan media ini merupakan skala ordinal dan dapat digunakan dengan skala liker, dengan bobot nilai 4, 3, 2, 1. Dengan sekala liker, maka variabel yang akan di ukur dijabarkan menjadi indikator variabel. Selanjutnya data yang bersifat komunikatif indikator persentase (Suharsimi Arikunto, 2006), dan dapat di tulis sebagai berikut : 
Presentasi Kelayakan $\%=\left(\frac{\text { skor yang di observasi }}{\text { skor yang diharapkan }}\right) \times 100 \%$

Data yang terkumpul dianalisis dengan teknik analisis deskriptif kuantitatif yang di distribusikan dalam bentuk skor dan persentase kategori skala penilaian yang telah ditentukan. Lalu penyajian dalam bentuk persentase terebut di deskripsikan dan di ambil kesimpulan tentang mesingmesing indikator.

aspek dalam media pembelajaran yang dikembangkan menggunakan tabel berikut

Tabel 1. Skala Persentase Kelayakan Media Menurut Suharsimi Arikunto

\begin{tabular}{lll}
\hline Persentase Pencapaian & Angka & Katagori \\
\hline $76-100 \%$ & 4 & Sangat layak \\
\hline $56-75 \%$ & 3 & Layak \\
\hline $26-55 \%$ & 2 & Cukup \\
\hline $0-25 \%$ & 1 & Kurang Layak
\end{tabular}

\section{HASIL DAN PEMBAHASAN}

\section{Hasil}

Adapun hasil uji yang dilakukan dalah sebagai berikut :

\section{a. Hasil Uji Oleh Ahli Media}

Tabel 2. Hasil uji oleh ahli media

\begin{tabular}{cccc}
\hline No & Ahli & Prosentase & Keteramgan \\
\hline \multirow{2}{*}{1} & Ahli & $100 \%$ & Sangat layak \\
\hline
\end{tabular}

Pada pembobotan dengan menggunakan skala Likert skor maksimal yang di hasilkan adalah 48 sedangkan skor yang diperoleh dari penelitian adalah 48 . Maka dari data tersebut dapat diketahui tingkat kelayakan media pembelajaran komputer terapan jaringan berbasis Adobe Flash CS6 dari ahli media adalah 100\%. Sesuai kriteria yang ditetapkan maka media pembelajaran komputer terapan jaringan termasuk dalam katagori sangat layak.

\section{b. Hasil Uji Oleh Ahli Materi}

Tabel 3. Hasil penilaian ahli materi

\begin{tabular}{cccc}
\hline No. & Ahli & Prosentase & Keteramgan \\
\hline \multirow{2}{*}{1} & Ahli & $93 \%$ & Sangat layak \\
\hline
\end{tabular}

Dengan pembobotan skala liker skor maksimal yang harus didapat adalah 40 sedangkan skor yang di dapat adalah 37 maka dari data tersebut dapat diketahui tingkat kelayakan media pembelajaran komputer terapan jaringan berbasis Adobe Flash CS6 dari ahli media adalah 93\%. Sesuai kriteria yang ditetapkan maka media pembelajaran komputer terapan jaringan termasuk dalam katagori sangat layak.

\section{c. Hasil Uji Oleh Pengguna}

Tabel 4. Hasil penilaian oleh pengguna

\begin{tabular}{cccc}
\hline No. & Ahli & Prosentase & Keteramgan \\
\hline 1 & Pengguna & $86 \%$ & Sangat layak \\
\hline
\end{tabular}

Berdasarkan skor dengan menggunakan sekala Likert oleh pennguna sebanyak 26 siswa skor maksimal yang dihasilkan adalah 1075, dengan skor yang di per oleh dari penelitian adalah 1249 maka dari data tersebut diketahui tingkat kelayakan media pembelajaran komputer terapan jaringan dari uji coba pengguna adalah $86 \%$. Sesuai kriteria yang ditetapkan maka media pembelajaran komputer terapan jaringan dalam katagori sangat layak, data terlampir.

\section{Pembahasan}

Dari rumusan masalah yang telah disampaikan maka perbahasan akan menekankan pada poin-poin permasalahan yang akan di bahas satu-persatu dengan melihat pada data hasil uji coba yang telah diperoleh yang sesuai dengan teori yang disampaikan oleh Daryanto (2010) dan Sugiyono (2009). Terdapat beberapa perbedaan penelitian yang dilakukan penulis dengan penelitian yang relevan yang dilakukan oleh Hasrul Basri (2010) dan Fajar Santosa (2008) meliputi, perangkat lunak peneliti merupakan 
perangkat lunak yang dibuat sendiri dan disempurnakan sehingga tampilan dan tool lebih lengkap dan mudah digunakan, dan pembahasan yang disampaikan mencakup materi tentang jaringan komputer hingga komponen-komponen dari jaringan komputer dan terdapat latihan soal yang dapat digunakan untuk menguji kemampuan siswa dan dapat digunakan pada Windows dan Android sehingga dapat digunakan di mana saja dan kapan saja jadi dibandingkan peneliti sebelumnya yang mencakup pada pengertian dan pengenalan jaringan komputer dan hanya bisa digunakan di Windows. Berikut ini pembahasan dari masing-masing permasalahan :

\section{Desain Media Pembelajaran Merakit Komputer Berbasis Adobe Flash CS3}

Berdasarkan hasil rancangan dan saran-saran yang diberikan, baik dari ahli materi maupun ahli media maka dilakukan pembuatan media pembelajaran dengan tiga tahap yang di sampaikan Sugiono (2009) meliputi: desain materi, desain navigasi dan desain tampilan.

Desain materi di rancang sesuai dengan standar kompetensi pada sub pokok bahasan komputer terapan jaringan, Yaitu: Menjelaskan Komputer terapan jaringan, Jenis-jenis jaringan komputer, komponen jaringan komputer, menjelaskan komputer minimal, dan menyebutkan mikro kontrolir.

Tahap desain navigasi dan tampilan layar di susun dengan mengacu pada karakteristik multimedia pembelajaran yang meliputi: bersifat interaktif, mampu memperkuat respons pengguna dengan cepat, pengguna navigasi berupa (tombol untuk melanjutkan , tombol untuk mengulangi/kembali, tombol untuk kembali ke homer). Untuk mengetahui alur dari aplikasi di buatlah diagram alir yang terdiri dari simbol-simbol untuk mempermudah mendeskripsikan rancangan aplikasi yang dibuat.

Dan untuk mempermudah dalam pembuatan tampilan dan tata letak tombol maka dibuatlah Stor biar yang terdiri dari sekumpulan sketsa yang menunjukkan rangkaian dari aplikasi yang dibuat.

\section{Realisasi Media Pembelajaran Komputer Terapan Jaringan Dengan Adobe Fslah CS6}

Merealisasikan media pembelajaran komputer terapan jaringan dilakukan dengan beberapa tahap meliputi : Pembuatan Stor biar yang menunjukkan rancangan dasar dalam pembuatan media pembelajaran komputer terapan jaringan untuk merealisasikan pembuatan media pembelajaran.

Stor biar yang digunakan sebagai acuan meliputi:

a. Halaman pembuka yang berisi intro yang menampilkan animasi logo IKIP Veteran Semarang.

b. Halaman masuk yang terdiri dari judul materi media pembelajaran dan tombol masuk ke halaman utama media pembelajaran.

c. Halaman menu kompetensi dasar terdiri dari kompetensi-kompetensi yang dapat di pilih dan di pelajari tentang materi pembelajaran komputer terapan jaringan.

d. Halaman isi kompetensi dasar yang menampilkan isi penjelasan dari kompetensi dasar

e. Halaman menu materi yang berisi materi-materi yang bisa dipilih dan dipelajari.

f. Halaman isi materi yang berisi penjelasan materi komputer terapan jaringan

g. Halaman soal yang berisi latihan soal dengan 10 soal yang diacak dan tiap soal benar di beri nilai 10 dan soal akan diberi nilai 0 .

Penggunaan software untuk merealisasikan media pembelajaran diantara-Nya : Adobe Flash CS6 yang digunakan untuk membuat media pembelajaran yang berisi tool-tool dan bahasa pemrograman untuk membuat animasi dan memberikan perintah yang dapat menjalankan pergerakan dan perpindahan halaman pada media yang 
dibuat, Corel Draw X8 yang digunakan untuk membuat tombol-tombol dan latar belakang.

\section{Uji kerja Media Pembelajaran Komputer Terapan Jaringan berbasis Adobe Flash CS6 di SMK Al Furqon Demak}

Berdasarkan hasil uji coba penggunaan media pembelajaran, dapat diketahui unjuk kerja sebagai berikut:

a. Dari aspek media meliputi: media yang di buat ada beberapa tombol yang harus di benahi seperti penempatan tombol dan terjadi eror pada saat di klik sehingga perlu adanya perbaikan pada media pembelajaran agar menunjang kenyamanan dalam penggunaan, ukuran font dan batas-batas dari teks juga disesuaikan agar mudah dibaca.

b. Dari aspek materi meliputi : dari aspek materi komputer terapan tidak ada kekurangan atau ke tidak sesuaikan dengan materi yang diajarkan di SMK Al Furqon Demak.

4. Tingkat kelayakan media pembelajaran komputer terapan jaringan berbasis Adobe Flash CS6 di SMK Al Furqon Demak.

Tingkat kelayakan media pembelajaran komputer terapan jaringan berbasis Adobe Flash CS6 dalam penelitian ini menggunakan instrumen yang telah di konsultasikan dengan cara penilaian oleh ahli media, ahli materi, dan pengguna media. Berdasarkan penilaian dapat diketahui tingkat kelayakan sebagai berikut:

\section{a. Ahli media}

Ahli media menguji tingkat kelayakan media pembelajaran komputer terapan jaringan dari Ketua Jurusan Pendidikan Informatika IKIP Veteran Semarang, dengan penilaian dari segi tampilan sudah bagus dengan komposisi warna yang sudah tepat, konsistensi antar slide sangat konsisten, dari segi navigasi mudah dipahami dan digunakan dengan baik, kemudahan dalam penggunaan dan kesesuaian dengan materi sangat baik. Dari beberapa hal yang disampaikan oleh ahli materi diketahui tingkat kelayakan adalah sebesar $100 \%$ dan dikategorikan sangat layak.

\section{b. Ahli materi}

Ahli media menguji tingkat kelayakan media pembelajaran komputer terapan jaringan dari guru TKJ di SMK Al Furqon Demak dengan penilaian aspek kualitas materi dan manfaat materi sudah sesuai dengan materi yang disampaikan dan kesesuaian dengan tujuan pembelajaran di SMK Al Furqon. Dari pendapat ahli materi yang telah diampaikan dapat diketahui tingkat kelayakan sebesar $93 \%$ dan dikategorikan sangat layak.

\section{c. Pengguna}

Uji produk oleh pengguna diuji coba kepada 26 siswa kelas X Teknik Komputer Jaringan SMK Al Furqon Demak, penilaian yang dilakukan meliputi aspek tampilan media bias dipahami dengan baik oleh pengguna, sangat mudah dalam pengoperasian media dan dengan adanya media pembelajaran komputer terapan jaringan sangat mempermudah dalam memahami materi dengan tingkat kelayakan sebesar $86 \%$ dan di kategorikan sangat layak.

\section{SIMPULAN}

Berdasarkan hasil penelitian dan pembahasan, maka dapat di ambil kesimpulan sebagai berikut.

1. Desain yang di rancang adalah desain pembuatan media pembelajaran komputer terapan jaringan berbasis Adobe Flash CS6 dengan tahapan desain materi yang disesuaikan pada materi yang diajarkan di SMK AL Furqon, desain navigasi dan tampilan layar yang di susun mengacu pada karakteristik multimedia yang baik dan penggunaan mid mapping serta struktur peta navigasi yang telah dirancang.

2. Tingkat kelayakan media pembelajaran komputer terapan jaringan berbasis Adobe Flash CS6 di uji tingkat kelayakan oleh ahli media dengan persentase tingkat kelayakan sebesar 
$100 \%$ dan oleh ahli materi dengan persentase tingkat kelayakan sebesar 93\% dan uji coba pengguna media pembelajaran dengan tingkat kelayakan sebesar $86 \%$ dan secara kesimpulan dikategorikan sangat layak sebagai alat bantu pembelajaran.

\section{Daftar Pustaka}

AECT. "The Definition of Education

Tecnology”.(1977). Edisi Indonesia

Dengan judul Definisi Teknologi

Pendidikan. Jakarta : CV Rajawali.

Azhar Arsyad. (2010).Media

Pembelajaran. Jakarta: PT. Raja

Grafindo Persada.

Damayanti, Laily E.(2011). Media

Pembelajaran Berbasis Multimedia

Bumi dan Alam Semesta. Skripsi.

Yogyakarta: Universitas Negeri

Yogyakarta.

Sugiyono. (2006). Statistika untuk

Penelitian. Bandung:Alfabeta

Sugiyono. (2009). Metode Penelitian

Pendidikan ( Pendekatan kuantitatif, kuaiitatif dan R\&D) Bandung:

Alfabeta.

Suharsimi Arikunto. (2006). Prosedur

Penelitian Suatu Pendekatan Praktik.

Jakarta: Rineka Cipta. 